\title{
SISTEM INFORMASI PENGELOLAAN NILAI MAHASISWA BERBASIS WEB PADA STMIK STIKOM INDONESIA
}

\author{
Komang Kurniawan Widiartha ${ }^{1}$, Made Dona Wahyu Aristana² \\ STMIK STIKOM Indonesia \\ Jl. Tukad Pakerisan No.97 Denpasar Selatan, Bali. 80225 \\ Email: komang.kurniawan@stiki-indonesia.ac.id, aristana@stiki-indonesia.ac.id
}

\begin{abstract}
The scores management system conducted by the STMIK STIKOM Indonesia institution is still done manually, where the lecturer writes in the form of physical or paper assessment which is then re-input by the staff of the Academic Administration Bureau (BAAK) into the existing system. This has an impact on the ineffectiveness and inefficiency in the process of scores management and presentation in the form of report on the recapitulation of values that require long enough for the students. It takes a computerized system in the management of values that can accelerate the process of scores management, where the lecturers directly perform input and scores management into a system that is synchronized with the academic system as well as information in the form of a report of value to the party in need. The system to be designed and built is a web-based student information management system. In this study, the main objective is to facilitate lecturers and staff in the management of student scores and manufacture of computerized assessment report recapitulation.
\end{abstract}

Keywords: information system, scores management, student scores

\section{PENDAHULUAN}

STMIK STIKOM Indonesia (STIKI), merupakan salah satu perguruan tinggi bidang komputer di Denpasar. Sebagai sekolah tinggi yang berbasiskan komputer, segala kegiatan akademik dalam mendukung setiap proses bisnis yang ada, tidak terlepas dari peranan sebuah komputer beserta aplikasinya.

Dari semua kegiatan akademik yang ada, misalnya di akhir semester, dosen pengampu setiap mata kuliah mengumpulkan rekapitulasi nilai ke bagian biro administrasi akademik (BAAK). Untuk selanjutnya pihak BAAK akan menginputkan nilainilai tersebut ke dalam sistem akademik (SISKAD).

Cara BAAK menginputkan nilai ke siskad, dengan cara menginputkan satu per satu nilai setiap mahasiswa per setiap kelas yang ada. Hal ini akan membutuhkan waktu kurang lebih satu minggu untuk menginputkan semua nilai di setiap kelas. Waktu tersebut masih terasa kurang, dikarenakan beberapa dosen melakukan perbaikan terkait nilai yang sudah dikumpulkan. Kegiatan ini berlangsung setiap semester dan kegiatan ini memiliki prioritas yang tinggi di akhir semester.

BAAK selaku bagian administrasi di STIKI, tidak hanya melakukan kegiatan tersebut. Banyak kegiatan administrasi yang diselesaikan BAAK setiap harinya. Permasalahan yang timbul dari kegitan ini adalah lamanya waktu dalam penginputan nilai, tugas pokok BAAK yang lainnya tersingkirkan dikarenakan deadline untuk menyelesaikan laporan penilaian dan sering kali BAAK mengalami human error dalam penginputan nilai dikarenakan kelelahan.

Siskad yang ada, belum memiliki fitur importer nilai massal dengan dukungan format file excel. Di lain sisi, siskad didukung dengan database yang terintegrasi akan memudahkan diakses melalui media dan aplikasi yang lainnya. Hal ini mendorong kemunculan aplikasi yang menggunakan database siskad perlu dibangun untuk mendukung kinerja siskad yang ada. Oleh karena itu, penulis ingin mengangkat topik untuk merancang dan membangun sebuah sistem informasi yang dapat memudahkan pihak BAAK dalam melakukan rekapitulasi nilai akhir semester dengan judul "Sistem Informasi Pengelolaan Nilai Mahasiswa Berbasis Web pada STMIK STIKOM Indonesia".

\section{Sistem Informasi}

Jogiyanto (2005:12) Sistem Informasi menurut John Burch dan Gary Grudnitski terdiri dari komponen-komponen yang disebut dengan istilah blok bangunan (building block), yaitu blok masukan (input block), blok model (model block), blok keluaran (output block), blok teknologi (technology blok), blok basis data (database block) dan blok kendali (controls block). Keenam blok tersebut harus saling berinteraksi satu sama lain untuk mencapai sasaran dalam satu kesatuan.

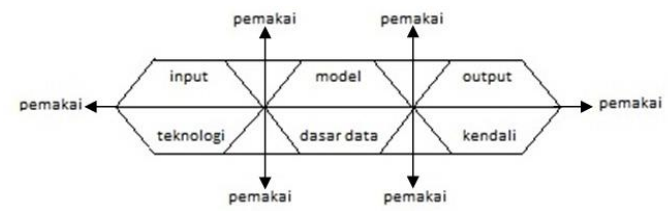

Gambar 1. Komponen Sistem Informasi

a. Blok Masukan

Input mewakili data yang masuk ke dalam sistem informasi. Input disini termasuk metodemetode dan media yang digunakan untuk menangkap data yang akan dimasukkan, yang dapat berupa dokumen-dokumen dasar.

b. Blok Model

Blok ini terdiri dari kombinasi prosedur, logika, dan model matematik yang akan memanipulasi data input dan data yang tersimpan di basis data dengan 
cara yang sudah ditentukan untuk menghasilkan keluaran yang diinginkan.

c. Blok Keluaran

Produk yang dihasilkan dari sistem informasi adalah keluaran yang merupakan informasi yang baik serta bermanfaat dan dokumentasi yang berguna untuk semua tingkatan manajemen semua pemakai sistem.

d. Blok Teknologi

Teknologi merupakan sebuah tool-box dalam sistem informasi. Teknologi digunakan untuk menerima masukan, menjalankan model, menyimpan, dan mengakses data, menghasilkan dan mengirimkan keluaran dan membantu pengendalian dari sistem secara keseluruhan. Teknologi terdiri dari 3 bagian utama, yaitu teknisi (humanware atau brainware), perangkat lunak (software) dan perangkat keras (hardware).

e. Blok Basis Data

Basis data (database) merupakan kumpulan dari data yang saling berhubungan satu dengan yang lainnya, tersimpan di perangkat keras komputer dan untuk mengakses atau memanipulasinya digunakan perangkat lunak yang disebut dengan DBMS (Database Management Systems). Data perlu disimpan dalam basis data untuk keperluan penyediaan informasi lebih lanjut. Perlu dilakukan pengorganisasian terhadap basis data yang ada agar informasi yang dihasilkannya baik dan efisiensi kapasitas penyimpanannya.

f. Blok Kendali

Banyak hal yang dapat merusak sistem informasi, seperti bencana alam, kecurangankecurangan, kegagalan-kegagalan yang terjadi di dalam sistem, ketidakefisienan, sabotase, dan lain sebagainya. Sehingga beberapa pengendalian perlu dirancang dan diterapkan untuk meyakinkan bahwa hal-hal yang dapat merusak sistem dapat dicegah ataupun bila terlanjur terjadi kesalahan - kesalahan dapat langsung cepat diatasi.

\section{Data Flow Diagram}

Data Flow Diagram (DFD) adalah representasi grafik dari sebuah sistem. DFD menggambarkan komponen-komponen sebuah sistem, aliran-aliran data di mana komponen-komponen tersebut, dan asal, tujuan, dan penyimpanan dari data tersebut. Penggunaan DFD memiliki dua hal utama, yaitu untuk membuat dokumentasi dari sistem informasi yang ada, atau untuk menyusun dokumentasi untuk sistem informasi yang baru.

Tabel 1. Simbol DFD

\begin{tabular}{lll}
\hline Simbol & $\begin{array}{l}\text { Nama } \\
\text { simbol }\end{array}$ & \multicolumn{1}{c}{ Keterangan } \\
\hline \hline Entitas & $\begin{array}{l}\text { Simbol entitas } \\
\text { eksternal/terminator, } \\
\text { menggambarkan asal } \\
\text { atau tujuan data di luar } \\
\text { sistem }\end{array}$ \\
\hline
\end{tabular}

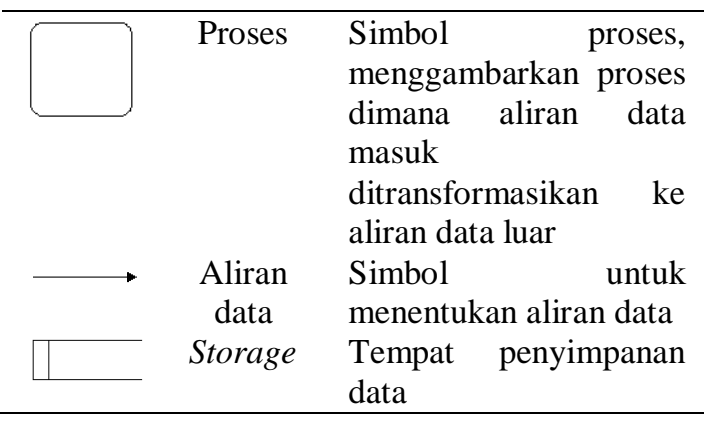

Database

Definisi database sebelumnya cukup umum; misalnya, kita dapat mempertimbangkan sebagai kumpulan kata-kata yang membentuk halaman teks ini menjadi data yang terkait. Namun, penggunaan umum dari istilah database biasanya lebih terbatas. Database memiliki sifat implisit sebagai berikut:

a. Database mewakili beberapa aspek dunia nyata, terkadang disebut miniworld. Perubahan ke dunia mini tercermin dalam database.

b. Database adalah kumpulan data logis yang koheren dengan beberapa komponen yang melekat. Berbagai macam data secara acak tidak dapat disebut sebagai database.

c. Database dirancang, dibangun, dan dihuni dengan data untuk tujuan tertentu. Hal ini memiliki kelompok pengguna yang diharapkan dan beberapa aplikasi yang telah terbentuk sebelumnya.

Sistem database terdapat komponen-komponen utama yaitu perangkat keras (hardware), sistem operasi (operating system), basis data (database), program aplikasi (application program), DBMS (Database Management System), dan pengguna (user).

\section{Database Management System (DBMS)}

Untuk mengelola database diperlukan suatu perangkat lunak yang disebut DBMS (Database Management System). DBMS merupakan suatu sistem perangkat lunak yang memungkinkan user (pengguna) untuk membuat, memelihara, mengontrol, dan mengakses database secara praktis dan efisien. Dengan DBMS, user akan lebih mudah mengontrol dan memanipulasi data yang ada. Dalam konsep database, urutan atau hierarki database sangatlah penting. Urutan atau hierarki database digambarkan dalam Gambar 2.

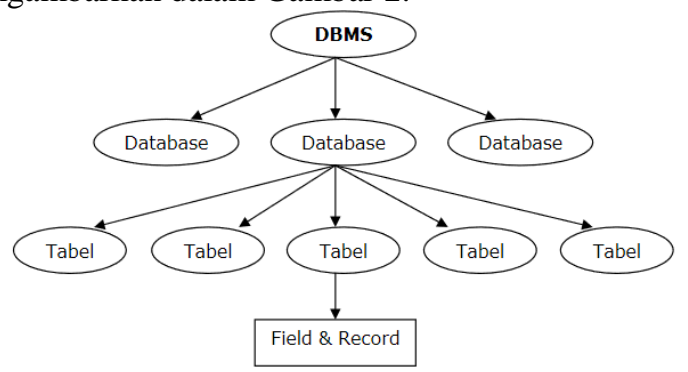

Gambar 2. Hierarki database 
Kebanyakan DBMS menyediakan mekanisme pengaturan sekuritas (keamanan) terhadap basis data berdasarkan wewenang pengguna. (keamanan) terhadap basis data berdasarkan wewenang pengguna. Beberapa DBMS memiliki fasilitas query yang memudahkan pengguna dalam mengakses dan mendapatkan informasi. Gambar 3 menggambarkan komponen dari sebuah DBMS.

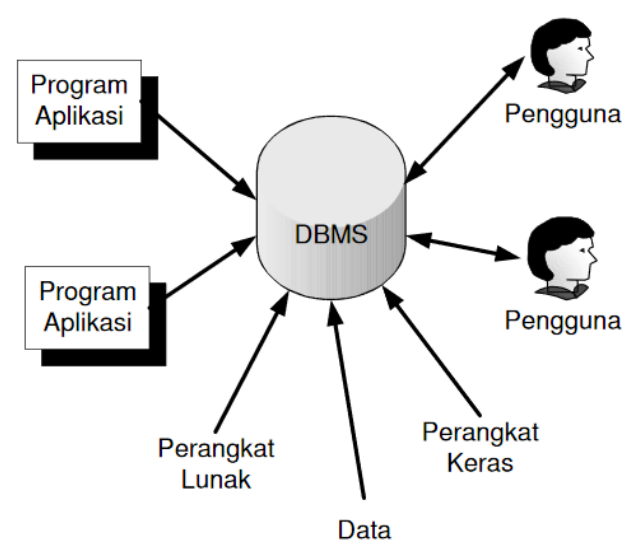

Gambar 3. Komponen DBMS

\section{Nilai}

Nilai adalah sesuatu yang berharga, bermutu, menunjukkan kualitas, dan berguna bagi manusia. Sesuatu itu bernilai berarti sesuatu itu berharga atau berguna bagi kehidupan manusia. Nilai dalam hal ini adalah sesuatu dari hasil belajar. Pengertian hasil belajar adalah perubahan perilaku secara keseluruhan bukan hanya salah satu aspek potensi kemanusiaan saja. Artinya penilaian hasil belajar tidak dilihat secara fragmentasi atau terpisah, melainkan komprehensif.

Menurut Bloom, hasil belajar mencakup:

a. Kemampuan kognitif yaitu knowledge (pengetahuan), comprehension (pemahaman, menjelaskan, meringkas, contoh), application (menerapkan), analysis (menguraikan, menentukan hubungan), synthesis (mengorganisasikan, merencanakan, membentuk bangunan baru), dan evaluation (menilai)

b. Kemampuan afektif yaitu receiving (sikap menerima), responding (memberikan respon), valuing (nilai), organization (organisasi), characterization (karakterisasi), rountinized (rutin)

c. Kemampuan psikomotorik mencakup keterampilan produktif, teknik fisik, sosial, manajerial, dan intelektual.

Menurut Suprijono hasil belajar adalah polapola perbuatan, nilai-nilai, pengertian-pengertian, sikap-sikap, apresiasi dan keterampilan. Menurut Gagne, hasil belajar meliputi informasi verbal, keterampilan intelektual, strategi kognitif, keterampilan motorik, dan sikap. Menurut Lindgren, hasil belajar meliputi kecakapan, informasi, pengertian, dan sikap.

\section{METODE PENELITIAN}

Metodologi penelitian yang umum digunakan adalah action research, expertiment, case study dan survey [1]. Dalam penelitian ini yang digunakan penulis adalah penelitian case study, yaitu penelitian yang melibatkan penyelidikan pada situasi tertentu. Penelitian dilakukan dengan tahapan menganalisa permasalahan, pengumpulan data, analisa kebutuhan sistem, studi pustaka, desain dan perancangan sistem sampai dengan pembangunan sistem yang digambarkan pada Gambar 4.

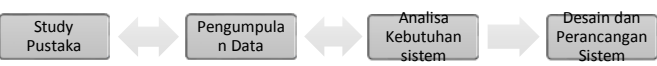

Gambar 4. Bagan tahapan penelitian

\section{Study Pustaka}

Dalam penelitian ini, beberapa teori penunjang sebagai acuan dalam melakukan perancangan. Teori sebagai bahan referensi tersebut berupa buku teks dan jurnal serta prosiding yang terkait. Referensi berupa buku teks digunakan penulis sebagai dasardasar yang digunakan dalam perancangan sistem, pembangunan user interface dan code program dalam implementasinya. Sedangkan jurnal dan prosiding penulis gunakan untuk mempelajari penelitian yang berkaitan dan yang bersifat kebaruan. Semua referensi yang digunakan masih dalam lingkup perancangan sistem informasi.

\section{Pengumpulan Data}

Pengumpulan data dilakukan dengan studi literatur dan observasi pada objek penelitian.

\section{a. Observasi}

Pada pengumpulan data dengan teknik observasi, penulis melakukan pengamatan langsung terkait proses pengelolaan nilai yang dilakukan oleh Biro Administrasi Akademik (BAAK) di STMIK STIKOM Indonesia. Didapat hasil bahwa dalam pengeolaan masih dilakukan dengan beberapa langkah dan dirasa sangat membutuhkan waktu dan resource. Dengan proses tersebut dirasa kurang efisien dan kurang efektif.

b. Wawancara

Dalam wawancara, penulis melakukan wawancara dengan staff Biro Administrasi Akademik. Dari wawancara yang dilakukan, didapatkan hasil bahwa staff sering kekurangan waktu untuk melakukan penginputan nilai ke sistem dari form fisik yang diberikan masing-masing dosen dikarenakan staff mengerjakan tugas pokok dalam administrasi akademik.

c. Dokumentasi

Dalam pengumpulan data menggunakan metode dokumentasi, penulis memperoleh data seperti data form fisik penilaian, data mahasiswa, data dosen dan data staff dari Biro Administrasi Akademik.

\section{Analisa Kebutuhan Sistem}

Dalam penelitian ini dilakukan analisa sistem dengan menggunakan dua tahap, yaitu tahap analisa 
sistem yang sedang berjalan dengan menggunakan Document Flow Diagram dan tahap analisa sistem baru yang dihasilkan dengan menggunakan System Flow Diagram untuk menjawab permasalahan yang ditemukan dalam analisa tahap pertama.

a. Analisa tahap pertama

Proses dimulai pencetakan form penilaian ujian akhir semester (UAS) yang berisikan kolom-kolom nilai yang harus diisikan oleh dosen bersangkutan. Form tersebut dicetak melalui sistem informasi akademik (SISKAD) yang ada oleh staff Biro Administrasi Akademik (BAAK). Setiap dosen pengampu kelas akan mendapatkan form penilaian tersebut, nantinya untuk diisi rekapitulasi penilaian akhir mahasiswa dan dikumpulkan kembali ke BAAK. Proses selanjutnya staff BAAK menginputkan masing-masing penilaian per kelas ke dalam siskad. Dalam penginputan lembar form fisik direkap kembali.

b. Analisa tahap kedua

Dalam analisa tahap pertama ditemukan permasalahan adalah borosnya form penilaian yang dicetak BAAK, penginputan ke sistem akademik yang membutuhkan waktu yang lama dan juga adanya proses pencatatan secara berulang oleh dosen ke form penilaian fisik yang dilanjutkan penginputan secara sistem oleh BAAK.

Dalam analisa kedua, proses dimulai dari dosen login ke sistem penginputan nilai, selanjutnya dosen dapat mendownload template form penilaian masing-masing kelas yang diampu. Setelah penilaian diisi ke dalam templete form penilaian, dosen dapat mengunggahnya kembali melalui sistem, dan secara otomatis penilaian dari sistem penginputan nilai tersinkronisasi ke siskad.

\section{Desain dan Perancangan Sistem}

Semua proses yang terlibat menjadi kesatuan sistem yang terkomputerasi dengan aliran data digambarkan dengan data flow diagram. Sedangkan dalam merancang database, pada penelitian ini menggunakan entity relationship diagram yang digambarkan dengan model conceptual data model.

a. Data Flow Diagram (Level Konteks)

Diagram Konteks adalah komponen Pemodelan Fungsional yang berdiri sendiri sebagai alat yang berharga. Ini memungkinkan tim atau individu menghasilkan model tingkat tinggi dari sistem yang ada atau yang direncanakan yang menentukan batas sistem kepentingan dan interaksinya dengan elemen kritis di lingkungannya. Diagram Konteks adalah gambar tunggal yang memiliki sistem menarik di bagian tengah, tanpa rincian struktur atau fungsinya di dalam, dikelilingi oleh elemen-elemen di lingkungan tempat ia berinteraksi [2]. Sistem informasi pengelolaan nilai mahasiswa melibatkan tiga entitas, yaitu admin, dosen dan akademik. Ketiga entitas berhubungan dengan sistem dalam aliran data di setiap proses yang ada. Admin lebih kepada maintenance profil dan setting, entitas dosen terlibat dalam aliran data nilai dan akademik mengatur aliran data seperti data mata kuliah, mahasiswa, kelas dan laporan. Gambar 5 menggambarkan context diagram dari sistem yang dibangun.

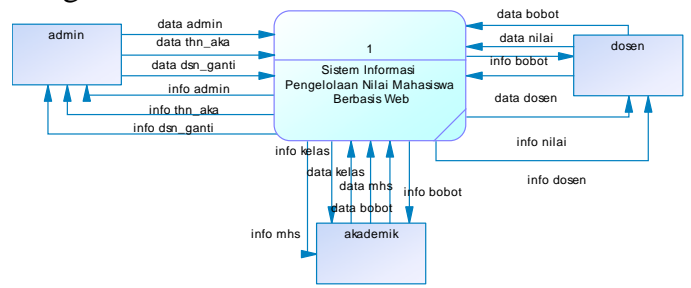

Gambar 5. Context Diagram

b. Entity Relationship Diagram

Entity relationship diagram mendefinisikan hubungan antar dua entitas. Kerelasian menjadi suatu kejadian atau transaksi yang terjadi diantara dua entitas yang ketergantungannya perlu disimpan dalam basis data [3]. Dalam penggambaran relasi antar entitas dalam sistem ini, digunakan pemodelan dengan menggunakan conceptual data model untuk menggambarkan secara detail struktur hubungan entitas dalam bentuk konseptual atau logika. Conceptual Data Model terdiri dari objek yang tidak diimplementasikan secara langsung ke dalam basis data yang sesungguhnya [4]. Gambar 6 menggambarkan conceptual data model dalam menggambarkan hubungan entitas dalam sistem yang dibangun.

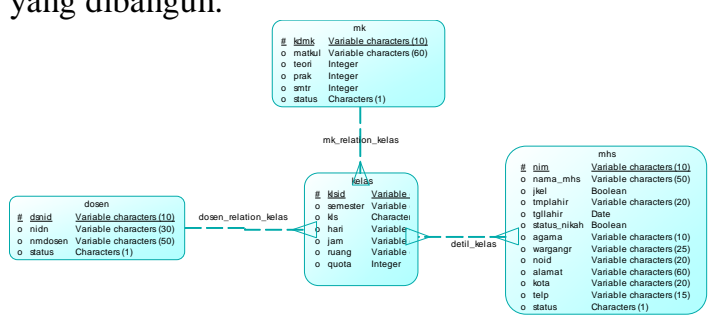

Gambar 6. Conceptual Data Model

c. Perancangan Database

Proses pemilihan struktur penyimpanan yang spesifik dan pengaksesan file-file database untuk mencapai kinerja yang terbaik di bermacam-macam aplikasi, dibutuhkan perancangan database sebelum implementasinya. Basis data adalah suatu kumpulan data yang disusun dalam bentuk tabel-tabel yang saling berkaitan dan disimpan secara bersama dalam suatu media elektronik [5]. Dalam pembangunan sistem ini, perancangan database secara fisik digambarkan dengan physical data model, dimana penggambaran ini dihasilkan dari mengenerate secara langsung dari conceptual data model. Gambar 7 menggambarkan perancangan database menggunakan physical data model. 


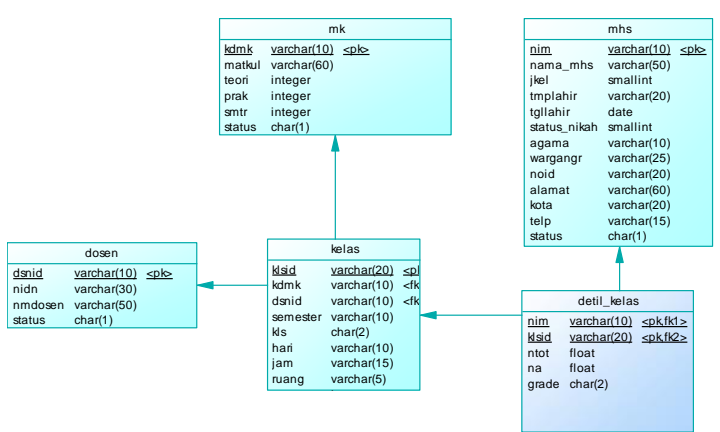

Gambar 7. Physical Data Model

\section{HASIL DAN PEMBAHASAN}

Dari tahapan penelitian yang dilakukan, hasil dari sebuah perancangan yang merupakan hasil atas pengimplementasian perancangan ke dalam sistem yang dibangun. Beberapa hasil dibahas sebagai berikut:

a. Login form

Sebelum dapat mengolah nilai, user (admin, dosen dan staff) harus melakukan login untuk dapat masuk ke dalam sistem. Gambar 8 menggambarkan halaman implementasi untuk login.

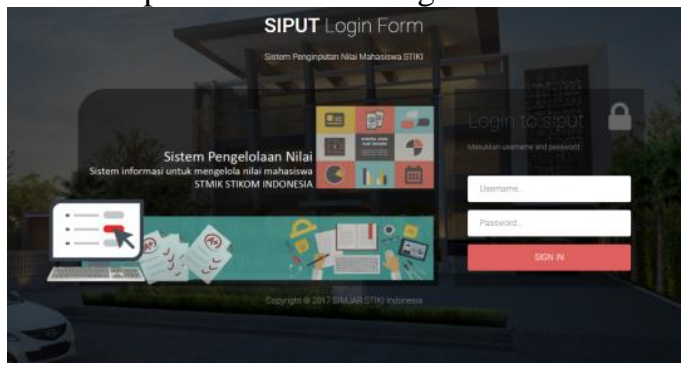

Gambar 8. Form Halaman Login

Setelah dapat masuk ke dalam sistem, user akan dibawa ke halaman dashboard sesuai level user.

b. Admin (BAAK)

Gambar 6 menggambarkan dashboard dari user admin. Staaf Biro Administrasi Akademik selain sebagai level staff, user ini juga difungsikan untuk level admin. Dalam halaman ini, terdapat menu samping kiri yang digunakan untuk mengelola nilai, mencetak laporan rekapitulasi nilai, melakukan setting seperti setting user dosen, setting tahun akademik, setting bobot nilai, setting tanggal penginputan dan setting dosen pengganti mata kuliah. Halaman dashboard user admin/staff menampilkan informasi mengenai jumlah nilai yang terinput per kelas dan per mahasiswa dari total keseluruhan kelas dan mahasiswa.

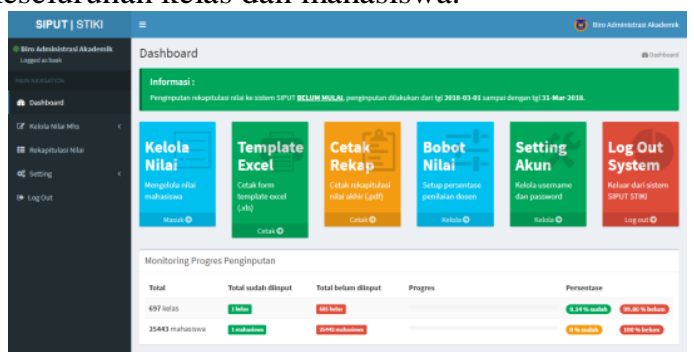

Gambar 9. Dashboar user level admin/staff
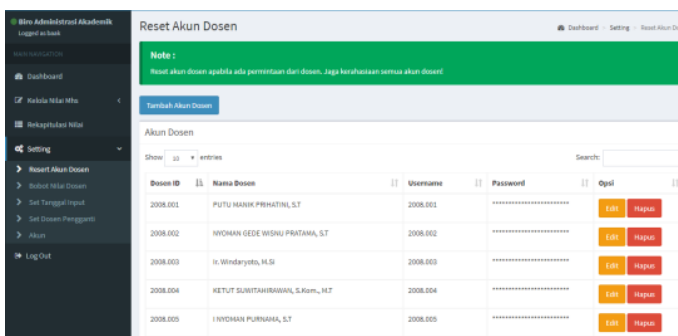

Gambar 10. Setting akun dosen

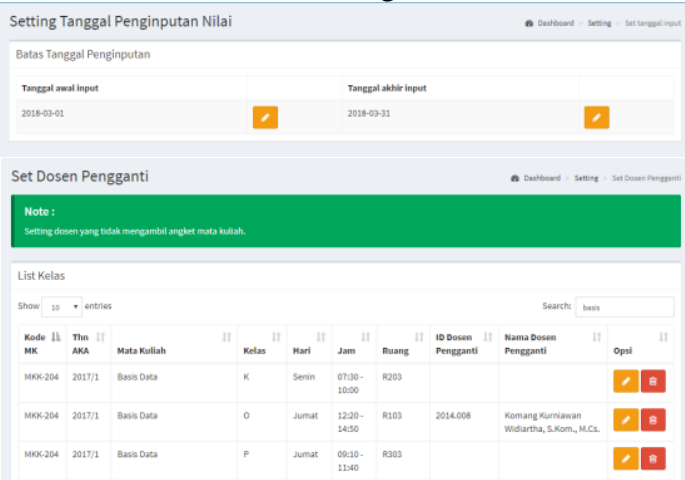

Gambar 11. Setting dosen pengganti

c. Dosen

Berbeda dengan user level staff/admin, pada user level dosen, fitur yang ada lebih kepada pengelolaan nilai kelas dan mahasiswa selain juga dapat melakukan setting profile user sendiri dan mencetak laporan rekapitulasi di kelas yang diampu.

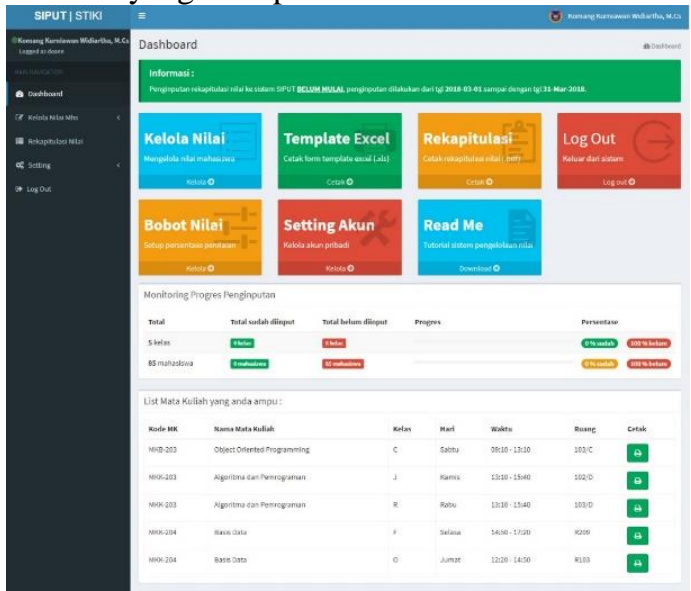

Gambar 12. Dashboard user level dosen

Dalam melakukan pengelolaan nilai, dosen memilih kelas beserta mata kuliah yang ingin dikelola nilainya yang ditunjukkan pada Gambar 10 . Setelah itu dosen ditujukan pada halaman kelola nilai mahasiswa. Di halaman ini dosen dapat melakukan kelola nilai dengan cara mengedit satu per satu dari mahasiswa per kelas yang diampu dan dapat juga melakukan dengan cara melakukan import ke sistem dengan file excel yang sudah didownload sebelumnya berupa templete form nilai yang ditunjukkan pada Gambar 13. 


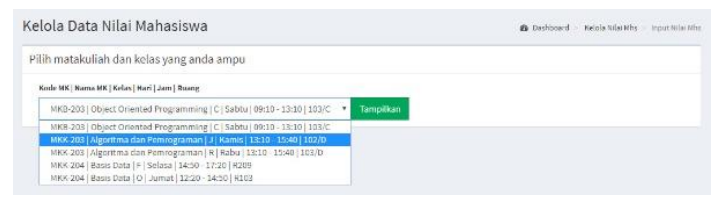

Gambar 13. Pemilihan kelas user dosen

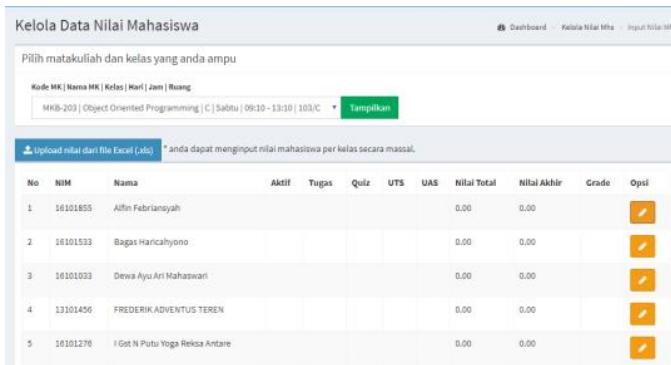

Gambar 14. Halaman pengelolaan nilai

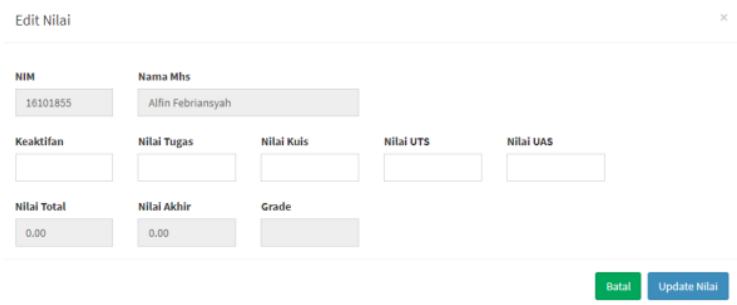

Gambar 15. Halaman edit nilai

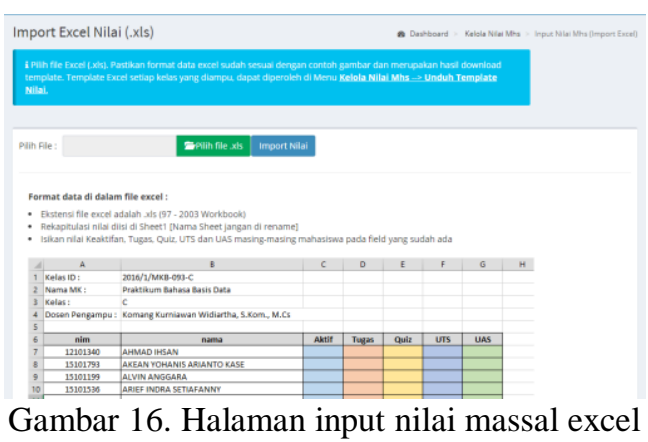

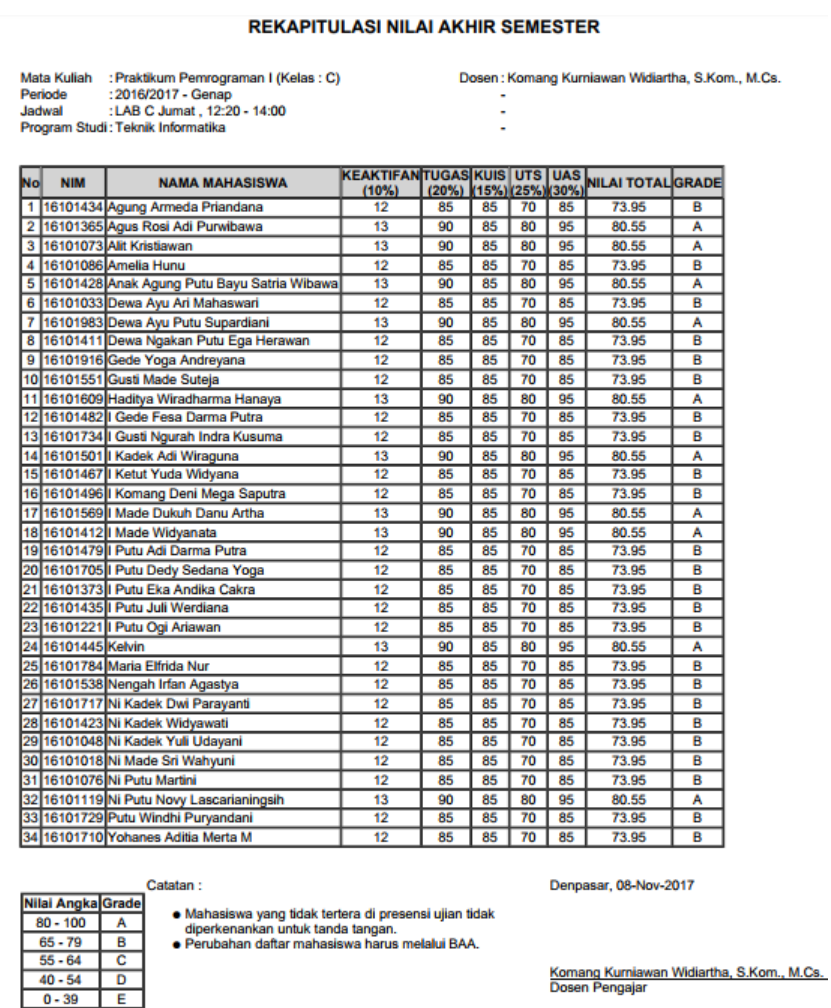

Gambar 17. Laporan rekapitulasi nilai

\section{KESIMPULAN}

Berdasarkan hasil penelitan melalui perancangan, impelemntasi dan analisa yang sudah dilakukan, dapat disimpulkan beberapa hal sebagai berikut:

a. pengelolaan data nilai secara manual dengan proses penulisan ke dalam form penilaian secara fisik dan menyerahkan ke staaf Biro Administrasi Akademik dan diinputkan secara manual ke sistem menuai permasalahan dari sisi efisiensi waktu yang dibutuhkan staff. Selain itu adanya proses penginputan secara berulang yang dilakukan oleh dosen dan staff adalah sebuah kegiatan yang tidak efektif dilakukan.

b. Pengelolaan nilai dengan sistem dititik beratkan pada efektifitas pengelolaan nilai yang dilakukan oleh dosen ke dalam sistem pengelolaan nilai yang secara langsung tersinkroniasi ke sistem akademik. Hal ini akan mempermudah staff dalam pengelolaan nilai, karena langsung dilakukan oleh dosen tanpa harus menuliskan di form penilaian secara fisik. Yang berdampak pada efisen waktu dan kertas.

c. Dalam sistem yang dibangun menyediakan fitur seperti pengaturan sistem, setting pengelolaan nilai, export templete form penilaian, import file excel penilaian secara otomatis dosen maupun staff dapat mencetak laporan yang dibutuhkan terkait rekapitulasi nilai mahasiswa.

\section{REFERENSI}

[1] C. W. Dawson, "Projects in Computing and Information Systems A Student's Guide A 
Student's Guide Second Edition."

[2] S. Burge and W. Churchill, "The Systems Engineering Tool Box," 2011.

[3] "Data Modeling - From Conceptual Model to DBMS," no. Sparx Systems, p. 18, 2011.

[4] T. Teorey, S. Lightstone, and T. Nadeau, Database Modeling and Design : Logical
Design, Fourth. San Francisco: Elseiver Inc, 2006.

[5] R. Elmasri and S. B. Navathe, Fundamentals of Database Systems, Sixth. New York: Pearson, 2010. 
Halaman Sengaja Dikosongkan 